\title{
ECI2 wt Allele
}

National Cancer Institute

\section{Source}

National Cancer Institute. ECI2 wt Allele. NCI Thesaurus. Code C113256.

Human ECI2 wild-type allele is located in the vicinity of $6 \mathrm{p} 24.3$ and is approximately $20 \mathrm{~kb}$ in length. This allele, which encodes enoyl-CoA delta isomerase 2, mitochondrial protein, plays a role in fatty acid metabolism. 